\title{
The Spirituality of Conversion
}

\begin{abstract}
"Although she is but one, she can do all things, and while remaining in herself, she renews all things; in every generation she passes into holy souls and makes them friends of God, and prophets" (Wis 7, 27).
\end{abstract}

This quotation from the Book of Wisdom clearly emphasizes some aspects of the theme of this reflection. It lies within the bounds of the great religious reforms that occurred between the sixth and second centuries $\mathrm{BC}$ between the Indus Valley and Egypt, passing through the mystic reforms in Greece. Pastoral ministry and catechesis are called upon to collaborate with Wisdom so that the message enters the heart to form true believers.

Stating that conversion is the work of the Trinity and in particular the action of the Spirit is not something that surprises. Perhaps for the "missionary conversion" of catechesis it is useful to deepen the "spiritual" nature of this inner transformation and not only liturgical and sacramental transformation. Even more, it may be useful to consider that the transforming action of the Spirit takes place jointly through the spiritual realm and the psycho-social realm, that it is anthropological. The activation of the Spiritual -spiritual dynamics is important both at the time of the first conversion that is the initial adhesion to the Gospel and in the permanent and deep conversion. ${ }^{1}$ Reflecting on the

1 This contribution utilises my two previous contributions on contemporary catechetics: Educare la risposta della fede. La receptio fidei compito della catechesi di "Nuova Evangelizzazione", «Urbaniana University Journal» 56 (2013) 3, p. 117-161 and „Effatà. Apriti”. La spiritualità della persona via della formazione cristiana, in: D. Scaiola (a cura di), Percorsi di spiritualità. La missione nel mondo di oggi, Urbaniana University Press, Città del Vaticano 2014, p. 115-129. 
"spiritual dimension of conversion" allows us to expand on how to overcome the paradigm of "a ministry of religious socialization (or social catechumenate)"2 and at the same time answer to the needs of our time, that is, „a missionary pastoral ministry" for conversion, for the maturity of faith and for the formation for Christian proficiency in life."3

\section{The Tasks of Catechesis in the European context}

It seems that the problem of the NE (= New Evangelisation) in the West is linked only to the transmission or the presentation of the faith. Undoubtedly for the future of Christianity in Europe there is a problem linked to the communication of the message. For many centuries the Church has moved away from culture and cannot communicate with it. It did not accept that part of the values of secularized modernity are also its values. It was afraid of the changes to which it was called with the result that for the first time in history, it did not take the path of inculturation but that of the defence of tradition at times even in a violent way. If we do not address this issue we have not so much the death of Christianity as much as its cultural marginalization in hearts of the people. This problem is felt in all European churches.

The dissociation between faith and culture is manifested in different ways. In particular the dissociation between the languages of faith and the languages of culture must be emphasized. For the future of Christianity it is inevitable to relocate the objective aspects of the faith in subjective human experience. We will have to accept that the understanding (interpretation and hermeneutics) of faith needs a reinterpretation of itself as a language. In this way it can regain its proper significance. It must also encompass the role that personal freedom

${ }^{2}$ The expression by C. Floristan can be applied in a general way: "I have said it many times: in the ancient Church it was the convert who was baptised. Today the baptised has to convert. This anomaly is in line with the excessive importance given to sacramental grace which is placed above the faith of the individual and which is not foreign to the pastoral obsession of baptizing ('quam primum') those who does not enjoy the use of reason, and gives the last rites (today, anointing of the sick) to those who have lost their reason" in: Il catecumenato, Borla, Città di Castello 1993, p. 36.

${ }^{3}$ L. Meddi, Compiti e Pratiche di Nuova Evangelizzazione; C. Dotolo, L. Meddi, Evangelizzare la vita cristiana. Teologia e Pratiche di Nuova Evangelizzazione, Cittadella, Assisi 2012, p. 79-150; here p. 94 . 
should have against the truth of the Christian message and the relationship with cultures and religions. The attempt to bypass this obvious and indispensable acquisition of modernity is putting forward many proposals for the NE exalt only the size of the relational communication at which it is aimed and at building new styles and expressions of Christianity but to adhere to the tradition through an affective and an emotional way.

However ecclesial interpretations diverge when considering the role religious language plays in different European contexts. ${ }^{4}$ There appear to be three polarizations which are not necessarily territorial. In the first (which is prevalent in northern Europe) religious language is not absent but very secularized, that is linked to anthropological expressions in the a-religious line already proposed by Dietrich Bonhoeffer. In the second (found in the East) religious language has suffered from the ambiguity of the Church as an institution during the different communist occupations with the consequence that people have a preconceived vision of religion as an institution, thus also stifling their religious feelings. In the third (found in the south-west Europe) religious language is still very strong, expressing much of the culture of the people, but it is definitely being separated from its original forms. At the heart of the NE in Europe we can therefore put the issue of the development of a new Christian form capable of evolving progressive separations.

The NE constitutes a truly communication problem. But the separation between faith and culture is not just a matter of proper communication. It is also linked to accompanying inner change; of the receptio that allows a response of the faith. The separation between faith and life is a socio-cultural as well as psycho-cultural reality. It is linked to the interior life. It is a result of the crisis which one remembers, but it is also linked to the inability of catechesis and other educational realities (primarily pastoral ministry and liturgy) to develop the integration of faith and life in catechumens. ${ }^{5}$ The question of the NE must

${ }^{4}$ D. Hervieu-Leger, La religione degli europei. Fede, cultura religiosa e modernità in Francia, Italia, Spagna, Gran Bretagna, Germania e Ungheria, Ed. della Fondazione Giovanni Agnelli, Torino 1992; E. Biemmi, La catechesi in Europa. Una nuova 'geografia della fede' per un nuovo primo annuncio del Vangelo, "Catechesi» 79 (2009) 1, p. 3-15. The European Catechesis Team has studied this theme in the Congress of Graz (Catechesis in the Context of Popular Religiosity, 2006).

${ }^{5}$ L. Meddi, Educare la risposta della fede, p. 147-149; L. Meddi, Il compito della catechesi nella nuova evangelizzazione. Superare la dissociazione fede e vita, «Catechesi» 82 (2012-2013) 2, p. $12-18$. 
be read as an educational crisis. The crisis in fact is manifested as the initiated adult's inability to give witness, to assume a missionary co-responsibility, to overcome religious individualism, and a disinterest in the liturgy and the lacking missionary co-responsibility.

The theme of conversion fits right in this aspect of religious language (Christian) in the different European contexts as a matter of twofold inculturation/ integration: cultural and personal. It is not only a matter that relates to the time when one proposes the faith, but especially to the time of the qualification of the witness of the community and its ability to develop an internal spiritual dynamism.

Finally it is important to note that reflecting on a deep conversion means developing a theory of adequate catechesis. Other ministries should also take on the task of evangelisation. Evangelisation is called to support the response that is the receptio of the faith; in other words, the task that is performed by the addressee. The Church proclaims, but it is the person who is called to join the message and to change one's life project and path. ${ }^{6}$ As John Paul II wrote, we must be aware that "the human being ... is the first and the fundamental way of the Church"7

\section{Conversion: an Event and a Spiritual Process}

The analysis of the documents and of the ideas of different Authors on the topic of "conversion" is too wide to be fully reported in this brief reflection. These will be kept in the background in order to identify the theme of the spiritual dimension of conversion itself in a special way. A much greater attention will be given to the documents of the universal Church since it is these that are driving the way in which the catechetical mission in the different ecclesial realities is developing.

\section{Magisterial Reflections}

The documents before Vatican II put the accent on the implantatio ecclesiae and then baptism with the immediate objective of a missionary preaching. In Maximum Illud (1919) the theme is still absent. A global reading of the most

${ }^{6}$ L. Meddi, La persona nell'atto catechistico, «Via, Verità e Vita» 42 (1993) 145, p. 46-52; L. Meddi, Catechesi e persona in prospettiva educativa, «Catechesi» 81 (2011-2012) 3, p. 3-13.

7 Redemptor Hominis, 14. 
important conciliar and post-conciliar documents helps us to understand that the theme of conversion shares a Trinitarian nature. They also identify different pastoral perspectives for its realisation. In fact we have three perspectives: the gospel-spiritual setting of $\mathrm{AG}$ (= Ad Gentes), the vision of conversion as the evangelization of the culture of the subject and of groups of individuals of EN (= Evangelii Nuntiandi), and the ecclesiocentric perspective (doctrinal and sacramental) of RM (= Redemptoris Missio).

AG (1965) in paragraph $13^{8}$ contains three dense reflections. The first offers us a description of the purposes, of the subjects and of the steps in conversion. In the second part it describes the path and the process of conversion. AG in fact distinguishes between the initial conversion and the entire spiritual journey of conversion. In the third part it focuses on the necessary intra-psychic conditions. In the first place, the transformation of the perceptual field of the individual and of the sphere of personal trends (,a passage which implies a progressive change in outlook and morals"); then the transformation of one's social definition (,it must become evident within the consequences of social order"). The issue of progressive inner healing is also emphasised because „whoever has converted undergoes a break with the past and detachments." Finally, the text recalls the decisive point of the whole process: inner freedom, and not only the politics of such freedom. Indeed it says that ,it strictly forbids forcing or enticing people to embrace any faith by trickery."

The General Catechetical Directory (1971) ${ }^{9}$ offers us two valuable considerations. The first states that the aim of conversion is to evangelise but it is "[also] aimed at those who have not yet given a true personal adherence to the revealed message" (p. 18). In the second consideration, it explicitly speaks of the inner help of the Holy Spirit. It describes how he moves the heart, opens the eyes of the mind, accepting and believing (p. 22, with a quotation from DV 5). So ,it is the task of catechesis to help people accept the action of the Holy Spirit." This task of the interior dimension of development is taken up again in p. 75 ("development of the activity and of the creativity of the catechized persons”).

${ }^{8}$ D. Grasso, La prédication missionnaire, in: J. Schutte, (director), Lactivité Missionnaire de l'Église. Décret «Ad gentes», Les édition du Cerf, Paris 1967, p. 225-270.

9 One has to note that the theme is not present in the Congress in which this text was prepared: Sacra Congregazione per il Clero, Atti del II Congresso Catechistico Internazionale di Roma, 20-25 settembre 1971, Studium, Roma 1972. 
Evangelii Nuntiandi (1975). EN reminds us that the kingdom and salvation which are keywords of the preaching of Jesus are a gift but also task, „each individual gains them through a total inner change that the Gospel designates by the name of metanoia, a radical conversion, a profound change of mind and heart" (p. 10). It is a constant process (p. 15); a process that involves the heart and the mind (p. 36). It will be useful to link this vision with the theme of dissociation, the positivity of the secularized culture, and the need to use human language (p. 63).

Catechesis Tradendae (1979). With CT there seems to be the start of a shift in the analysis of the nature and of the purpose of conversion. In CT, conversion is brought about by the first proclamation (p. 19), and has as its content the adhesion to the person of Jesus Christ as the only Lord with all one's heart. Consequently catechesis develops into conversion through a better knowledge of Christ (p. 20). Knowledge as a way of conversion is also affirmed in p. 49. Conversion must follow ,the revelation as transmitted by the universal Magisterium of the Church, in its solemn or ordinary form” through which one can "reach the profundity of the human being." Is this a neo-cognitivism? Maybe not, but the spiritual dimension is really almost cancelled.

Redemptoris Missio (1990). Initial conversion is described in p. 46-48 of RM, which are dedicated to ways (tasks) of missionary activity. Conversion and baptism are the fruit of the witness and of the first proclamation of Jesus the Saviour (p. 46). Conversion is a gift of God, a work of the Trinity: it is the Spirit who opens people's hearts, so that people can believe in Christ and „confess" faith. It is a dynamic and ongoing process that lasts a lifetime and demands a continual turning from „life according to the flesh” to „life according to the Spirit" (Rom 8,3 ) that is realized explicitly through baptism as mentioned in the title of the two paragraphs.

The General Directory for Catechesis (1997). ${ }^{10}$ We must recognize that GDC tries to make a synthesis of the settings already present in previous documents. The GDC deals with conversion especially in p. 53-57. These sections are organized according to two global coordinates. Conversion is presented as an act or decision of faith and as formation or continuing catechesis. It is described as a process that theologically includes some stages: the interest in the gospel,

10 The Catechism of the Catholic Church (1992) does not offer a full definition of conversion. It is elaborated in the chapters on morality; on the other hand it is not interested in developing the dynamics of conversion and of the missionary process. 
conversion, the profession of faith, the path to perfection. It is , a time of research which can be transformed into a firm option"; it is moved by the Holy Spirit and by the announcement of the kerygma and is a true "fundamental option" that is at the basis of the whole Christian life of the Lord's disciple (with citations from AG 13, EN 10, RM 45, VS 66, RCIA 10).

In short, we are faced with two polarizations. On the one hand, conversion is the work of the Spirit who is already present in people's lives. This dynamism leads to spiritual development and to the cultural transformation of the person which at times becomes an ecclesial belonging. One the other hand, conversion is a reply to the first proclamation, regards the adherence of the person to Jesus, takes place as a fruit of the action of the sacraments and should lead primarily to baptism. The two positions are reconcilable only if you think in an inclusive way. More exactly conversion is the process of the spiritual growth of the person with whom you gradually try to imitate (discipleship) Jesus, something which is signified in the act of baptism. At the heart of conversion then we have a transformation or a new creation and not simply faith.

The theological complexity is due to the reconsideration of the relationship between the missions of the Son and of the Spirit. It is a matter which primarily deals with the purpose of conversion that is metanoia, to become disciples and witnesses and not only adherence to the Christological doctrine of redemption. It also affects the pastoral dimension because this results in two possible pedagogies. One centred on the sacraments to be received and the other on the spiritual dynamics to be activated and to evangelize. This discussion is not new in the history of the Church. Today it takes on a renewed importance. Especially in the field of catechesis which is called not to remain in the sphere of announcing the Good News but to study and develop the routes for the personalisation of the message, its integration into one's life and to enable witnesses.

\section{The Evolution of Theological Reflection}

What do theologians write when they spoke of conversion? The analysis of the various university databases shows that the subject has had a theological-missionary beginning. Theologians focused on two interests: to develop the analysis of the vocabulary that in the NT is summarized in the expression metanoia; and the consequences of provocation launched by W. James ${ }^{11}$ on

11 W. James, The Varieties of Religious Experience. A Study in Human Nature, 1902. 
the relationship between theology and the inner life. From his investigation he concludes that the spiritual dimension belongs to the human dimension before the religious dimension. Among the contributions that we can identify as texts which make a synthesis we must remember those of Congar, ${ }^{12}$ Rahner ${ }^{13}$ and the much quoted Lonergan. ${ }^{14}$ For these authors conversion is a Spiritual -spiritual process.

This initial research was then followed by specific studies that highlight the different dimensions of conversion. ${ }^{15}$ While moral theology deepens penance as a way of conversion, spiritual reflections found themselves faced with the task of uniting the classical tradition with psychological reflection. ${ }^{16}$ While in Europe reflection seemed to run out, the theme was taken up in the US as an

12 Y.-M. Congar, La conversion, étude théologique et Psycologique, «Parole et Mission» 11 (1960) 11, p. 493-523, studies conversion and the fundamental task of theology through a biblical and phenomenological approach, and within this perspective it takes the psychic dimension. It tackles two pastoral themes: authenticity and the relationship with Christian confession.

${ }^{13}$ K. Rahner, Conversione, in: K. Rahner (a cura), Sacramentum Mundi, Morcelliana, Brescia 1974, II, coll. 622-631, with his usual lucidity proposes the central themes of conversion. In the pastoral reflection he indicates some decisive questions. Ministry must reflect on the process of conversion to Christianity in a context that is not centred on the choice of faith but only on ecclesial belonging. The care of souls and pastoral theology should not however forget the phenomenon of conversion as a key task of individual pastoral care. They should therefore be studied with more commitment to get to mystagogy in such a personal experience of conversion. Since the fundamental option must continually prove itself in new situations, it must therefore continuously be decisive; the key stages of life constitute also many situations and specific aspects of conversion.

${ }^{14}$ B. Lonergan, Metodo in Teologia, Città Nuova, Roma 2001, p. 163, provides a detailed definition: „To convert means the transformation of the subject and his world. Normally it is a long process although it may be explicitly acknowledged in some important judgments and decisions. However it is not only a development nor even a number of developments. The result is a substantial change of one's course and direction. It is as if their eyes were open and their own world lacked colour and crumbled. In its place there is something new that as a result has interconnected sequences and a cumulative development at all levels and in all areas of human life ... Conversion as an experience effects all conscious and intentional operations of human being. It directs his/her gaze, pervades his/her imagination, shakes the symbols that penetrate deep into his/her psyche. It enriches his/her understanding, guides his/her judgments, and strengthens his/her decisions."

15 A volume with many entries summarises the different dimensions: W. E. Conn (ed.), Conversion: perspectives on personal and social transformation, Alba House, New York 1978.

${ }^{16}$ H. Pinard de la Boullaye, Conversion, in : Dictionnaire de Spiritualité Ascétique et Mystique. Doctrine et Histoire. Tome II, Deuxième Partie, Beauchesne, Paris 1953, coll. 2224-2265. 
equivalent of the discussion on the progression toward maturity of faith that is the object of catechesis. In those years, in fact, the progress introduced by the RCIA (1972) and the psychosocial theories of J. Fowler were at loggerheads. This can be found in the national document of the North American Bishops. ${ }^{17}$ Attempts at an inclusive reading made by R. M. Mosely ${ }^{18}$ were not convincing. In this ecclesial context they continued to further deepen the relationship between conversion and the intrapsychic world studying all the anthropological dynamics involved, ${ }^{19}$ and especially the help of the human sciences. ${ }^{20}$ After a long time, the theme reappears only recently ${ }^{21}$ in the already known dimensions of theological research. ${ }^{22}$

It can be summed up by saying that conversion is both an event and a process, which has two acting subjects: the Trinity and the person; that its identity is contained in the expression "change" as a profound orientation of the whole life to the revealed word, a change that takes place in and through the psychological dimension of the person. It is therefore not a social act imposed from outside, solely intellectual. Many of these dimensions are justified with reference to Dei Verbum 5 (1965) as the completion of Dei Filius (1870).

${ }^{17}$ I refer to National Council of Catholic Bishops, Sharing the Light of Faith. National Catechetical Directory for Catholics of the United States, United States Catholic Conference, 1979; and to J. Fowler, Stages of Faith. The Psychology of Human Development and the Quest for Meaning, Herper Collins, New York 1981.

18 R. M. Mosely, Faith Development and Conversion in the Catecumenate, in: R. Duggan (edited by), Conversion and the Catechumenate, Paulist Press, New York 1984, p. 1445-1463. The text elaborates the theme to the theological sphere of the great religions, to the psycho-social dimensions and in the different dimensions of culture.

${ }^{19}$ H. Newton, S. Southard (eds.), Handbook of Religious Conversion, Religious Education Press, Alabama 1992.

${ }^{20}$ L. R. Rambo, The Psycology of Conversion, in: H. Newton, S. Southard, Handbook of Religious Conversion, p. 159-177.

${ }^{21}$ F. Giannoni, Conversione, in: G. Barbaglio, G. Bof, S. Dianich (a cura), Teologia, San Paolo, Cinisello Balsamo 2002, p. 292-303; R. N. Fragomeni, Conversione, in: M. Downey (diretto da), Nuovo dizionario di Spiritualità, Libreria Editrice Vaticana, Città del Vaticano 2003, p. 161-165; G. Colzani, Converirsi a Dio. Opera della grazia, scelta della persona, sfida per le chiese, Urbaniana University Press, Città del Vaticano-Roma 2004; G. Mossiere (directed by), La conversion, Faculté de Théologie et de Sciences des Religions de l'Université de Montréal, Montréal 2014.

${ }^{22}$ A useful synthesis is found in: M. Spindler, Conversion, in: I. Bria, Ph. Chanson, J. Gadille, M. Spindler, Dictionnaire oecuménique de missiologie. Cent Mots pou la mission, Cerf-Labor et Fides-Cle, Paris-Genève-Yaoundé 2001, p. 70-72. 


\section{Catechetical Reflection}

At first it seems that 20th century catechetics has not dealt with conversion not even in the first period of „missionary catechesis” (1950-1965). Notwithstanding this, we can find a rich reflection contained in other expressions. Following a chronological research we can say that the theme is present in catechetical reflection already at the time of the inquiry into the character of the faith that was posed by the question of the sociologist Le Bras: what happens when the French peasant leaves the country and arrives at the Gare du Lyon for business reasons? Why is his religious life lost?

A deep reflection can be found in the research by A. Godin who points out that non-converting and even regression in the journey of faith comes from an infantile persistence of representations of religious language. In his long experience $^{23}$ he has reported many times that the Christian proposal does not enter into the life experience of people and it does not direct their daily choices because it is limited to a magical and sacred socialization. It does not help them to overcome the religion of desire and the message is not intended as a guide to reality.

Following the reflections on the character of religion, Gc. Negri ${ }^{24}$ deepened the theme of religious formalism. This is a reflection that will bring the Italian catechetical sphere to formulate the famous words ,integration of faith and life" as a task of catechesis. This was understood as the development of the motivations for the Christian life. Integration is seen both as a result of intra-psychic operations but also of social operations: the quality of the proclamation, its relationship with the life of the recipient, the method of learning, and ecclesial relations. J. Colomb ${ }^{25}$ constructs the heart of this early proposal.

23 A. Godin, Le mete della catechesi nelle varie tappe dello sviluppo, in: Le mete della catechesi. Atti del $2^{\circ}$ convegno „Amici di catechesi”, Elledici, Torino 1961, p. 105-134; A. Godin, Psychologie des Experiences Religieuses, Centurion, Paris 1981.

${ }^{24}$ G. C. Negri, Considerazioni sul fenomeno della dissociazione tra sapere religioso e mentalità di vita, in «Orientamenti Pedagogici» 8 (1961), p. 269-297. The theme is restudied by Gc. Milanesi, Integrazione tra fede e cultura, problema centrale della pastorale catechetica, «Orientamenti Pedagogici» 14 (1967), p. 547-589; then inserted in the Documento Base. Il rinnovamento della catechesi n. 52, of the Italian Bishops in 1970.

${ }^{25}$ J. Colomb, Al servizio della fede. Manuale di catechetica, 2, Elledici, Torino 1970, c. VI; a catechesis of integration. Youth. His manual moreover presents several links with the Spirit especially on the theme of "faithfulness to the action of the Spirit", linking this to the active methods. 
It concerns the issue of conversion and also the definition of catechesis given by the General Catechetical Directory 1971 p. 21, for which its task is to drive the maturity of the faith, that is driving the transition from initial faith to grow in such a way as to encapsulate the entire Christian personality. We know how this expression was first emptied of its intrapsychic meaning and then abandoned.

Another way that catechetics has had to investigate the issue of conversion is encountered in pastoral ministry as a training to imbue Christian attitudes. The reflection by R. Tonelli is at the heart of this. ${ }^{26} \mathrm{He}$ refers to the theme of maturity in faith which is located in the integration of faith and life, and following the directions of W. G. Allport and A. Vergote sees Christian education as a development of faith understood in its anthropological dimension as an attitude which guides the personality. Catechesis helps a deeper conversion by supporting the reorganization of human attitudes in view of their unification in Christ. For these reasons A. Cañizares sees conversion as the specific task of missionary catechesis. ${ }^{27}$

Subsequently catechetics abandoned this reflection on conversion or progression of the faith ${ }^{28}$ perhaps for two reasons. On the one hand the irruption of the catechumenal model that seemed to respond to the theme of spiritual progression, exceeding the vision of catechesis as a cognitive progression; on the other hand with the emergence of the need to re-propose the message of the faith in a de-Christianized Europe. These reasons have made catechetical reflection study the objective of the message without taking into account the dynamics of its reception without wanting to.

\section{The Complex Dimension of Conversion}

This brief analysis has helped us to grasp the most significant aspects of the nature, tasks and steps which are proper to conversion. One might conclude that while documents emphasize the theological dimension, Authors are increasingly

${ }^{26}$ R. Tonelli, Educare agli atteggiamenti per l'integrazione fede e vita, «Note di Pastorale Giovanile» 9 (1975) 4, p. 28-34; Abilitare alla fede-speranza-carità, atteggiamenti fondamentali dell'esistenza cristiana, «Note di Pastorale Giovanile» 10 (1976) 7-9, p. 95-112.

27 A. Canizares Llovera, Catequesis misionera, «Teología y catequesis» 4 (1985), 1, p. 57-71 (here p. 62-64).

${ }^{28} \mathrm{~L}$. Meddi, Integrazione fede e vita. Origine, sviluppo e prospettive di una intuizione di metodologia catechistica italiana, Elledici, Torino 1995, c. V. 
confronted with the anthropological dimension. But maybe it is not so. It will be useful to show that even Magisterial reflections often refer to the subject of spirituality as a way of conversion, as a Trinitarian reference and as a development of different dimensions inside the person, and as a description of educational resources. In particular, the vocabulary used, such as "conversion of the heart, mind-mentality, habit" all show the changes or operations required of the person and which need to be constructed inside the catechumen.

A closer look at these dimensions and/or abilities shows that they always have an anthropological dimension, that is, they belong to the spiritual dimension of creation. As the theologians already mentioned have noted, "conversion” always has to do with transcendence but it is built on the decision of self-orientation towards a unifying point of one's human experience. It is related to the culture of the person or to the realization of one's self beyond the natural dimension. Conversion is therefore a transforming action that is achieved through learning processes. At the time of the first adhesion to the faith the person is involved at a motivational level. This means that the person adheres to the faith according to his/her wishes. This takes us back to the quality of communication and its significance; but even more to the authenticity of the motivations of why one accedes to the faith. This authenticity will be decisive for Christian transformation. In fact, it certainly involves the communication of the Christian proposal but even more the readjustment required of the person, of his/her attitudes and one's traits of life overcoming internal negativity. In this second phase the most important dimensions is overcoming internal resistance to the Gospel.

I consider this accompaniment as the main task of missionary catechesis. Catechesis arouses a response to the faith and to the receptio of the message inside the person's life in order to make a customization or internalization/ integration of the message itself. ${ }^{29}$ The need of a relationship between pastoral ministry and the way of learning of the person is rooted in the belief that receiving and interiorising are human activities. Any person, no matter his/her culture has received the task to welcome, encompass and adapt to the changing needs. This is the process of receptio that in the human sciences is defined in different and complementary ways. Sociology highlights how the receptio begins with the knowledge and the acceptance of the received tradition. For its part psychology has elaborated the principle of adaptation to express the correct relationship

${ }^{29}$ L. Meddi, Educare la risposta della fede, third part. 
between tradition and innovation. Based on these perspectives that describe the construction of the human person/personality, contemporary pedagogies have developed models and processes focussed precisely on this task. Pedagogy has better described itself as a process of socialization, education and inculturation. ${ }^{30}$ It has also rebalanced its proposal of values in terms of training towards self-care and inclusion in the tradition. ${ }^{31}$ The very complex aggregation of this ecclesial service can be summarized by the term development of the Christian personality.

Without wishing to belittle the ecclesial role of baptism, however, it will be useful to consider the theme of missionary conversion as hosting the Spirit who wants to form authentic people, believers, disciples and missionaries. This allows us to overcome the equivocal aspect of contemporary catechesis which reduces all catechetical process in the proposal of the message without making it interact with intrapsychic processes. It is a situation that is likely to reduce Christian formation solely to the cognitive dimension.

\section{The Spirituality of the Person as the Missionary Way}

I use the term spirituality ${ }^{32}$ with a triple meaning: the anthropological meaning that is the psychic and inner dimension of the person; ${ }^{33}$ the religious meaning that is the spiritual dimension of culture; ${ }^{34}$ the properly Christian (mostly Catholic) meaning that is the spiritual experience related to the revelation of Jesus of Nazareth. A three-dimensional vision. The pedagogy of the faith receives from it an equal and significant contribution although there are certainly differences in value. Spirituality is the dimension which gives direction and integrates the person. ${ }^{35}$

${ }^{30}$ C. Nanni, Educazione, socializzazione, inculturazione, «Orientamenti Pedagogici» 25 (1978) 4, p. 651-655.

${ }^{31}$ G. Chiosso, Teorie delleducazione e della formazione, Mondadori, Città di Castello 2004.

${ }^{32}$ K. Waaijman, Spiritualità. Forme, Fondamenti, Metodi, Queriniana, Brescia 2007.

${ }^{33}$ Cf. J.-F. Catalan, Psychisme et vie spirituelle, in : Dictionnaire de Spiritualité Ascétique et Mystique. Doctrine et Histoire. Tome XII Deuxiéme Partie, 1986, coll. 2569-2605; Spiritual awakening in: R. Assagioli, Lo sviluppo transpersonale, Astrolabio, Roma 1988, pp. 87-161.

${ }^{34}$ Religioni e pratiche formative, «Redemptoris Missio» 2 (2004) 20, p. 3-94; M. Vannini, La mistica delle grandi religioni, Mondadori, Milano 2004.

${ }^{35}$ A researcher in his latest research on the relationship between the psyche and the Spirit wrote: „the aim [of the text] is to discover or rediscover the exquisitely human dimension - the 
Vatican II gave us an initial reflection on the presence of the Spirit in the world. ${ }^{36}$ In LG the Spirit is identified with the Easter gift that only acts in and for the Church (LG 4) and this is the subject of the formation of the baptized (LG 35-37). This is an interpretation which is closely linked to the document on the liturgy, but it does not exclude that it is also present in the separated churches at least in the form of "methods" of salvation (LG 15). The conciliar texts have progressively developed the specific mission of the Spirit. In later texts, in fact we find that „undoubtedly the Holy Spirit was at work in the world before Christ was glorified” (AG 4). The „Spirit of the Lord [in fact] has filled the world” (GS 11); in the heart of all men of good will "grace is active invisibly ... we must hold that the Holy Spirit offers to all the possibility of being made partners, in a way known to God, in the paschal mystery" (GS 22). It is by virtue of this missionary presence that "from ancient times until today among various peoples there is a certain perception of that hidden force that is present in the course of things and the events of human life and indeed sometimes you recognize the supreme God or the Father. This perception and recognition penetrates their lives with a profound religious sense" (NA 2). The mission of the Spirit is described as operating, filling, giving strength, being present, being sensitive, an interior and intimate knowledge to the individual. Therefore, the Spirit precedes ${ }^{37}$ the Church's mission as a transforming agent in the heart of the people, in their culture and in their experiences: he is an inner and public agent.

These ideas have to be placed in the perspective introduced by GS (p. 10ff) of an anthropology of the Christian vocation which is not only called to recover the tripartite vision of the human being's identity and actions typical of the patristic period, but above all to show spiritual progression as inherent in creation and

„spirit" - understood here as the ability (and the duty) to understand themselves, others and the world; to take a certain position, to plan with a personal and responsible intentionality.... The "spirit”, as has been mentioned, is an excellent part of us and enables us to grasp the meaning of the „unique”, the "sense” of our life, its direction to social, political, moral, religious, relational, that is, to trace our life and move towards a goal with all the willingness to gradually accomplish the inevitable adjustments of the way"; cf. A. Ronco, S. Grammatico, Alla ricerca di Dio. Due ricercatori in cammino, Alpes, Roma 2016.

${ }^{36}$ We find a reconstruction in G. Canobbio, "Lo "Spirito" soffia dove vuole». Dove opera lo Spirito?» in La vita nello Spirito. Quaderni teologici del Seminario di Brescia, Morcelliana, Brescia 2012, p. 113-154.

37 Cf. la riflessione di Y. Congar, Les principer doctrinaux, in J. Schütte (under the direction of), L'activité Missionnaire de l'Église. Décret « Ad gentes », Les édition du Cerf, Paris 1967, p. 185-221 (189-190). 
not as an immediate moral remedy. According to Rulla, ${ }^{38}$ Vatican II showed sensitivity to the development of an anthropology of the Christian vocation in different places: the vocation of the human being is to overcome the inner split and dissociation.

\section{The Reconsideration of the Role of Spiritual Theology}

Like any other dimension of Christian life reflection on the spiritual experience has also gradually come to terms with the emerging new understanding of the role of the person and culture. As a result many theological issues linked to the rethinking of spirituality mark the contemporary era. ${ }^{39}$ First and foremost, with respect to the sources, recovering the Bible and Liturgy and recently the traditions of the Great Religions. It has deepened the tasks that were traditionally limited to the ascetic and mystical domains but which are now open to the anthropological, communitarian, historical and transformative dimensions with notable innovations in the aims and in spiritual practices.

Moreover, theologically it is constantly deepening the role of the Spirit in an original way when compared to that of Christ. This involves spiritual practices not related to the liturgical and sacramental dimension. These are proper to the first spiritual renewal and are more attentive to the dynamisms which are proper to the Spirit. To this perspective we can link the great development of spirituality as a therapeutic practice and as healing. ${ }^{40}$ This especially shows the spirituality of every human being as the basis of the same development of Christian spirituality.

Refocusing formation while having the person as a subject and not only as a recipient of the process means, in fact talking about his/her spiritual energies (both as a spirit as a Spirit). Spirituality becomes central in this redevelopment, offering significant contributions. This movement leads to the understanding

${ }^{38}$ We find a synthesis of his thoughts in L. M. Rulla, F. Imoda, J. Ridick, Antropologia della vocazione cristiana: aspetti conciliari e postconciliari, R. Latourelle (ed.), Vaticano II Bilancio e prospettive. Venticinque anni dopo, v. II, Cittadella, Assisi 1987, p. 952-1000.

39 J. Castellano Cervara, Teologia Spirituale, in: G. Canobbio, P. Coda (edd.), La teologia del XX secolo. Un bilancio 3. Prospettive pratiche, Città Nuova, Roma 2003, p. 195-321; B. Secondin, Nuovi cammini dello Spirito. La spiritualità alle soglie del terzo millennio, EP, Cinisello Balsamo 1990.

${ }^{40}$ J. Castellano Corvera, Il valore terapeutico della preghiera, «CredereOggi» (2005), 145, p. $95-110$. 
and development of the dimensions inherent in the person's life. Modern culture in fact calls for a unity between the acceptance of this mystery and interiorising it. From the spirituality of the person the way for an experience of faith is paved.

\section{The Paths of Spiritual Transformation}

Although using different formulations spiritual cultures have traced paths for the transformation of human nature. I will indicate some of these taking into account those that are already used in most itineraries of Christian formation.

\section{Christian Spirituality}

The history of Christian spirituality ${ }^{41}$ testifies that it has always represented the path for the formation of the baptized. To the formula of the two ways, taken from the teaching of Jesus, of the first communities and of St Paul there soon joined the idea of the growth of the faith as a development of the Christian life starting from Origen, of the experience of mystical union with God.

Tradition has preserved the memory that the Christian experience is a journey and an itinerary; they were given different descriptions but they agreed on three identical stages: that of beginners, characterized by the construction of the foundations of the way; of those who were progressing, characterized by the construction of the new dimensions of the human being; of the perfects, characterized by stability in the Christian life and of union with God. These paths intersect with dynamics and skills that are traditionally described as a purification through which one reorganizes the anthropological dimension and human dynamics; prayer that leads to the imitation of Christ and to integration according to the charisms of each one; contemplation which develops inner integration and the ecstasy that anticipates the realization of a unitive vocation. In this tradition, transformation is seen as overcoming the resistance of the ego to realize an openness to the will of God exceeding through self-knowledge, adherence to the mysteries of Jesus, a love relationship, the exercise

${ }^{41}$ G. Dumeige, Storia della spiritualità, in: S. de Fiores, T. Goffi (Ed.), Nuovo dizionario di Spiritualità, EP, Roma 1979, pp. 1543-1571; La lunga storia della teologia spirituale in: Aa.Vv., La teologia spirituale. Atti del congresso internazionale OCD. Roma 24-29 aprile 2000, Edizioni OCD-Edizioni del Teresianum, Roma 2001, pp. 21-202. 
of discernment and daily asceticism. This path opens to a relationship of communion with God or mysticism.

Three highly innovative experiences were the provisional results of this journey: the practice of the spiritual exercises of Ignatius, the description of the spiritual evolution of the person made by John of the Cross and the type of path proposed by Teresa of Avila. ${ }^{42}$ This is an afterthought which highlights the psycho-physical unity of the Christian experience; the responsibility for transforming the world and direct testimony; the development of their own charisms and their personalisation; and the use of the ways provided by religions.

In Christian spirituality, therefore, the path is centred more on steps one has to take to implement the new creation rather than on the contents to be transmitted or the simple steps of pastoral configuration. It is for this that it is strictly educational. It is a perspective centred on knowledge and the abandonment of the person to the theological truth but it does not lack the perspective of the psychological knowledge of the self.

\section{The Ways of the East}

There is no shortage of introductions to the understanding of the spiritual ways of the East in relation to what is specific to the Christian tradition. Among these we point out the compact study of M. Vannini ${ }^{43}$ for whom, excluding the differences of interpretation of the mystery of God the various religious traditions often meet each other in the description of the mystical path.

Mysticism does not analyse religious revelation but it has another knowledge that can be described in many ways and can be summarized in the way to overcome the desire to be, to be in power, to have, especially in relation to and in comparison to others through abandonment to God as the Other.

There is no doubt that the term and the key concept of the mysticism of the different religions lies in the concept of "detachment” as an abandonment of one's will to accept that of God. As Nostra Aetate recalls, the point of union

42 A. Tagliafico, Ignazio di Loyola e Teresa d'Avila: due itinerari spirituali a confronto Cristocentrismo, preghiera e servizio ecclesiale Edizioni OCD, Roma 2009; A. Grün, Mistica. Scoprire lo spazio interiore, Queriniana, Brescia 2011, p. 49-100.

${ }^{43}$ M. Vannini, La mistica delle grandi religioni, Mondadori, Milano 2004, cf. especially the Introduzione, p. 13-65. 
with Hinduism is precisely the progression of union-unity with the absolute through devotion or the desire to live realizing the principle of divine union. With Buddhism we have in common the Pauline theme of liberation, of interior dissociation which occurs through detachment from all desire to have only a desire for God (p. 2).

\section{The Recovery of the Unity of the Self}

By this expression I mean the psychological reflections aimed at overcoming the ego crisis of the West through those ways of overcoming the interior dissociation, the development of interiority and of potential energy. Often these come into conflict with the Christian tradition, they are often only psychological and not spiritual proposals. On the other hand they often interact purposefully with the Christian spiritual tradition.

\section{The Jungian Perspective.}

Various spiritual authors gladly re-take some of statements made by C. G. Jung. It is in this way that A. Grün, for example, presents the ideas of this Author: ${ }^{44}$ „C. G. Jung interprets the process of self-realization as a process of ongoing transformation. The goal of the human process of transformation is the union of opposites in self. The way of metamorphosis passes through the transformation of instinctual energy into another form [...]. Jung defines the 'transforming' symbols ... At a time when the opposites begin to talk amongst themselves, something changes in the human being. Such a transformation process, however, is not always visible. For a long time we do not feel anything about the inner change but then suddenly something in us changes. It is a vital process" (19-20).

\section{Psychological Perspectives from Freud to the Humanists.}

There are several Authors on religious formation who clearly insert paths of healing in itineraries of transformation from their childhood together with the

${ }^{44}$ La trasformazione in C. G. Jung in: Confidare nella trasformazione. Come la nostra vita diventa integra, Queriniana, Brescia 2007, 19-20. Cf. J. Sautermeister, Profilo teologico di Anselm Grün, www.queriniana.it/blog (7.01.2014). 
unconscious dimension of their actions.$^{45}$ Psychology has also elaborated the principle of adaptation to express the correct relationship between tradition and innovation. J. Piaget ${ }^{46}$ showed us how intelligence that guides our actions is the result of a continuous interaction and adaptation to external stimuli. The progressive interior change occurs as a balance between assimilation of the external cultural tradition and accommodation of the same tradition to our schemes of mental and vital needs. To this research, E. Eriksson ${ }^{47}$ added that the reception of culture takes place in relation to the cycles of life. It welcomes the knowledge-information that is perceived to be functional to the needs of life and abandon the performances which are perceived as unsuitable. Another part of humanistic psychology has developed the principle of the construction of the self through a process of integration of the personality and the elaboration of a personal life project. This development in conjunction with the existential philosophy of M. Heidegger is also understood as the specific task of the person in the course of life.

An important role in the ability to integrate oneself is played by the emotional memory. According to D. Goleman ${ }^{48}$ intelligence is not everything. What characterizes our behaviour and our personality is a mixture in which IQ merges with such virtues as self-control, tenacity, empathy and concern for others: in short, emotional intelligence. For M. Ricard, ${ }^{49}$ a Buddhist monk participating in the project of "contemplative neuroscience”, meditation, the transformative potential and compassion are related to the memory of negative and/or positive emotions.

\section{The Vision of Psychosynthesis}

Many Authors refer to psychological reflections that address the spiritual confusion of late modernity. These are reflections that are created to give back to the ideal self a place of control in human existence without which the person

${ }^{45}$ For the Italian context, I mention the tested proposals of M. Ballester, Meditazione profonda e autocoscienza, Emp, Padova 2007, e di M. Guzzi, Yoga e preghiera cristiana. Percorsi di liberazione interiore, Paoline, Milano 2009 [cf. www.darsipace.it (7.01.2014)].

\footnotetext{
46 J. Piaget, L'epistemologia genetica, Laterza, Bari 1971.

47 E. H. Erikson, I cicli della vita. Continuità e mutamenti, Armando Armando, Roma 1984.

${ }^{48}$ Intelligenza emotiva. Che cosè e perchè può renderci felici, Rizzoli, Milano 2011.

49 Esperienza interiore e neuroscienze, «Concilium» 51 (2015) 4, p. 23-36.
} 
remains fragmented and unable to face existence. It is for this that it is generically called the prospect of psychosynthesis. ${ }^{50}$ Among these Authors the work of R. Assagioli ${ }^{51}$ marks a significant contribution. The title of the collection of his essays and lectures of the 1920's to the 1930's shows his perspective well. He binds the proposed transformation of religions and psychologies highlighting that they are a unity in the description of the result by the person him/herself, and in the development of the capacity to enter into union with the whole universe. In this perspective, the vision of the Trinity as otherness is seen as the most appropriate interpretative key of all religious reflections. He describes the conversion-transformation process as an awakening, as a response to a crisis of a different type, as purification, as a control of negative impulses and as an overcoming of psychological and spiritual obstacles. ${ }^{52}$

\section{Educational Psychology in an Educational and Transformative Function}

Many Authors have listed psychological themes suited to the service of personal transformation. ${ }^{53}$ The most recurrent themes ${ }^{54}$ are those linked to the education of the perceptive capacity, the evolution of needs and reasons, the relationship between learning and faith, the development of the religious dimension, and faith as an attitude and life project. Until recently E. Morin ${ }^{55}$ warned that one can reach the way of the transformation of life through an educational reform.

${ }^{50}$ I refer to the hypotheses discussed in the first quarter of the $20^{\text {th }}$ century by R. Steiner, Guida alla comprensione del mondo spirituale, Libritalia, Città di Castello 1997.

51 R. Assagioli, Lo sviluppo transpersonale.

${ }^{52}$ In this perspective the reflections by A. H. Maslow on the sphere of the motivation of the person are very adapt.

${ }^{53}$ G. del Lago, Dinamismi della personalità e Grazia. Innesto dello sviluppo cristiano nello sviluppo psichico, Elledici, Torino 1970; A. Ronco, Integrazione psichica e virtù: elementi di una psicologia delle virtù umane, «Seminarium» 3 (1969), p. 531-544; A. Cencini, A. Menenti, Psicologia e formazione. Strutture e dinamismi, EDB, Bologna 1985; F. Imoda, Sviluppo umano, psicologia e mistero, EDB, Bologna 2005; M. Szentmartoni, In cammino verso Dio. Riflessioni psicologico-spirituali su alcune forme di esperienza religiosa, San Paolo, Cinisello Balsamo 2011; A. Manenti, Comprendere e accompagnare la persona umana. Manuale teorico e pratico per il formatore psico-spirituale, EDB, Bologna 2013; A. Cencini, A. Manenti, Psicologia e teologia, EDB, Bologna 2015.

${ }^{54}$ L. Meddi, Diventare educatore. Introduzione alla psico-pedagogia, Paoline, Roma 1989.

${ }^{55}$ La via della riforma di vita, Raffaello Cortina, Milano 2012, p. 241-256. 
He prefers the terminology related to "metamorphosis" achieved through a new quality of knowledge from the perspective of complexity and "relaying” (links and inner integrations to different knowledge) and this includes the spiritual perspective. In fact „The question of spirituality ... infiltrates a little bit everywhere in our society. As we lack an inner dimension, and the more the logic of the artificial machine invades us and oppresses us the more it infests the 'quantitative world of the more and more'. Thus what we lack becomes more a need: peace of mind, relaxation, reflection, the search for another life that responds to what is oppressed and suffocated within us" (244).

\section{The Proposal of Celestino's Prophecy}

It may seem out of place to mention Authors and proposals which are clearly from a new-age setting. ${ }^{56}$ However even this reflection highlights that in our time we are experiencing a new spiritual awakening caused by a critical mass of people who live their lives as a sort of spiritual development, a journey in which we all move forward guided by mysterious coincidences. The re-awakening is to be understood as a question of power because „we human beings now begin to realize that the universe we live in is made up of dynamic energy and not simple matter. All that exists is a field of sacred energy that we can sense and intuit ..." (3). In addition, ,insecurity and violence cease to exist when we experience an inner connection with the divine energy, a connection described by mystics of all religions ..." (5). It is clearly a proposal that ignores the Christian perspective but it expresses a useful dimensions for a pedagogy of inner transformation.

\section{The Philosophical Way}

As an extension of the aid practices which are proper to psychology and the overcoming of the difficulties which they manifest, a number of proposals were developed that see transformation as a path of knowledge by itself primarily

${ }^{56}$ C. Redfield, J. Adrienne, Guida alla profezia di Celestino, Corbaccio, Milano 1995. Cf. also J. Redfield, La decima illuminazione. Nuovi orizzonti della Profezia di Celestino, Corbaccio, Milano 1996; S. Redfield, J. Murphy, M. Timbers, Il lato spirituale della vita, Corbaccio, Milano 2002. Here I cite some of the nine texts which lead to "illumination" summarised in the synthesis on pp. 10-13. 
rooted in values, even unconscious values that have marked one's life from the very beginning. This is the case of the proposals of mythobiography of the School of Philo led by R. Màdera, in the perspective of Pierre Hadot. It is a program aimed at supporting the task of living, to understand and to promote the ability to become what you are, to discover and pursue your own personal myth and thus „compose your own history.” A „vocational” path that touches the entire person, developing their skills even in their professional responsibilities. ${ }^{57}$ Several Authors use their own method in the perspective of a deep conversion. ${ }^{58}$

\section{The Care of the Soul. A Personal Perspective}

Within this rich „transformative” perspective I consider it important to emphasize the encounter between spirituality and psychological analysis because in these two languages we also find others. The meeting is not motivated only by the possibility of a better communication of the spiritual fact, but above all from the fact that the anthropological sciences support the purposes of the spiritual journey. ${ }^{59}$

Already at the beginning of the century spiritual theology came to psychology in the sense of a phenomenological analysis of religious experience.$^{60} \mathrm{But}$ soon the relationship was studied in a more specific form. R. Zavalloni ${ }^{61}$ in the magazine of the Congregation for Catholic Education indicated that the input aimed at connecting the Christian tradition with the new human sciences comes from Vatican II. This has changed the initial negative approach and recognized the importance of the religious dimension; even pastoral ministry would do well in recognizing their contribution. A summary of the importance of the

${ }^{57}$ http://www.scuolaphilo.it/mitobiografica.html (7.01.2014). Cf. R. Madera, Una filosofia per l'anima, IPOC, Milano 2013.

${ }^{58}$ An example in: M. Diana, Una vita in gioco. Volume primo. Il cammino spirituale come percorso individuativo, Ipoc, Milano 2014 (two other volumes follow).

59 T. M. Courau, R. Ammicht Quinn, H. Haker, M. T. Wacker, Lessere umano al vaglio delle neuroscienze, «Concilium» 51 (2015) 4.

60 J. Schiettecatte, Teologia Spirituale e Psicologia: La controversia fra Anselmo Stolz e Gabriele di Santa Maria Maddalena, in: Aa. Vv., La teologia spirituale, p. 169-182.

${ }^{61}$ R. Zavalloni, L'apporto delle scienze dell'uomo alla vita spirituale, «Seminarium» 1 (1974) 1, p. 250-265. 
report was made by J.-F. Catalan. ${ }^{62}$ Recalling previous reflections he confirms that sanctification depends on the psyche, that grace and education go together and that spiritual maturity requires a certain degree of psychological maturity. The aid of the sciences that study the human psyche is also required in at least three spiritual situations: to deepen the character of life experience; to understand the role played by past experiences; to carry out a careful analysis of the motives at play in the growth of the faith, whether it is a religious need or need for God.

On this same wavelength we can place many contemporary spiritual reflections that are presented as paths to conversion and development of the faith. A. Grün states this clearly in his "foundational" book. ${ }^{63}$ For this popular spiritual writer this means combining spirituality and psychotherapy in the search for God: "for us it is important that the spiritual and the therapeutic levels are connected," as well as the methodology of individual spiritual exercises, prayer, meditation, the experience of the inner space of silence, an experience of integrity, the relationship between thoughts and feelings, our dark aspects, fears and needs, and the healing of wounds (65 ff.). S. Pacot ${ }^{64}$ warns us that a profound evangelization requires a path which tends to recompose the unity in one's being, constant listening to the Word of God, articulating all the way on the spiritual and the psychological level. In his Introduction he writes, „little by little, I became aware of the vital relationship between psychology and faith ... I became aware of the possible and necessary link between the psychological and the spiritual" (5-8). Similarly M. Guzzi ${ }^{65}$ who proposes a path of growth in the faith says that in the Church there is no need for a new inner spiritual path understood as an experience of interiority capable of integrating the Eastern practices like preparation tools, spiritual life and the practice of liberation (Introduction, 5-10).

${ }^{62}$ J. F. Catalan, Psychisme et vie spirituelle. Many reflections that are theoretical more than pedagogical have been studied for many years by many Authors from the « Gregorian School of Rome» and of the Tredimensioni periodical.

${ }^{63}$ A. Grun, La cura dell'anima. Lesperienza di Dio tra fede e psicologia, Intervista di J. Paulas e J. Šebek, Paoline, Milano 2004; A. Grun, Confidare nella trasformazione. Come la nostra vita diventa integra, Queriniana, Brescia 2007; on this aspect see also Mistica e psicologia, in his Mistica. Scoprire lo spazio interiore, p. 101-130.

${ }^{64}$ S. Pacot, L'Evangélization des Profondeurs, 2 vols., Editions du Cerf, Paris 2001.

${ }^{65}$ M. Guzzi, Yoga e preghiera cristiana. Percorsi di liberazione interiore, Paoline, Milano 2009. 


\section{Activating the spiritual senses}

„How come it's so hard to entrust ourselves to this mystery? ... Is it perhaps because we are 'bad'? Or because we are 'sick'? Perhaps is it only because we are weak, injured, confused, more than in other periods because the instability around us is increasing and it seems that we can do without reference points, at least those which are the strongest?" 66

Spiritual transformation is an action of the Spirit through the activation of the human psyche. This activation may be the new meaning given to asceticism and spiritual practices and could make a substantial contribution for accompanying conversion and Christian formation. Christian asceticism, the effort, the method, the spiritual struggle, the exercise, and discipline all indicate the human dimension of transformation, while mysticism comes to mean the abandonment to the Spirit and the experience of the Trinity. Christian conversion and transformation does not stand out for methods used but for the interpretation of divine action. ${ }^{67}$ Christian doctrine has always affirmed that progress does not depend on personal effort but on the docility to the Holy Spirit; the soul only needs to abandon itself to him. In concrete terms "surrendering” means offering a service and using human nature in view of the objectives of the Spirit. If the psychic dimensions are not developed properly they cannot support the action of the Spirit.

It is known that philosophical and Western Christian tradition have gradually manifested a distrust to what is of the senses. This led to the drying up and to the decrease of the sentimental, the affective and emotional elements in human experience, ${ }^{68}$ making way to the intellectual dimension. It is clear today that the spiritual senses are not intended as an alternative to the bodily senses but constitute the refining of those same senses enlightened by the Spirit. Limiting ourselves to the practice of transformation and neglecting mystical or contemplative practices we can point out some aspects of the heritage common to the various ways mentioned above. ${ }^{69}$

${ }^{66}$ F. Imoda, Introduzione, in: A. Cencini, A. Manenti, Psicologia e teologia, EDB, Bologna 2015, p. 7-8.

${ }^{67}$ Ch. Bernard, Ascesi, in: S. de Fiores, T. Goffi (a cura di), Nuovo dizionario di Spiritualità, EP, Roma 1979, p. 65-79.

${ }^{68}$ A. Montanari (ed.), I sensi spirituali. Tra corpo e Spirito, Glossa, Milano 2012.

69 An attempt at making a list can be found in: L. J. Gonzalez, Stimolazione spirituale. Tecniche e risorse di spiritualità pastorale, OCD, Roma 2004. 


\section{A Spiritual Pedagogy for Conversion}

I referred to a number ${ }^{70}$ of catechetical reflections in the 60 s and 70 s that have pointed out that the path of faith in the person occurs within the dynamics of the person him/herself. It is therefore important that pastoral ministry recognizes and knows how to make good use of these dynamics. In this research I am putting aside the developmental dimension of this process which will have to be re-addressed by catechetical experts in view of upgrading catechetical itineraries. It is useful to highlight how spirituality has many instruments to empower the deficiency of the self and the fluid $e o^{71}$ of our contemporaries. In fact we all experience and can verify both on a personal level and on the level of human groups the difficulty in managing daily life with reference to values.

In the face of such weakness pastoral ministry may follow the way of substitution through the creation of sub-cultures of the group or community with a strong membership which is continuously monitored and supported. This is the path followed by the new Christian movements. It can also pursue the path of healing the person/personality through a path which moves from awareness to the ego transformation. As already mentioned one could define this road as the way of a profound evangelization. In this perspective catechesis becomes a support to change and to personal growth creating interaction with the entire catechumenal path (I use the expression in the sense of a path of conversion towards baptism or the rediscovery of baptism, and the journey of Christian formation) modulated with a proposal of stages of spiritual growth more than on knowledge of the doctrine of the faith. The psycho-social transactions involved are often referred to as the motivational field, of the biographical memory, levels of ego development, and the relationship between the proposal and the developmental tasks of the person. As described even briefly this leads to review pastoral models defined in terms of inculturation (activities aimed at inserting a system of representations) but also as acculturation.

We must always keep in mind that these guidelines do not constitute the entire converting process, and above all it does not indicate the purpose and the content. These are given by the ecclesial tradition. The indications that are recalled form part of the chapter of educational goods suitable to promote the internalization of the Christian proposal.

\footnotetext{
${ }^{70}$ L. Meddi, La risposta della fede, p. 122-138.

71 Z. Bauman, Intervista sulla identità, Laterza, Roma-Bari 2003.
} 


\section{A Spiritual Awareness beyond Intellectualism}

Very often we hear reproaches addressed to "post-conciliar” catechesis by Authors and pastoral operators who attribute the failure of catechesis to its intellectual setting. ${ }^{72}$ Too often the solution proposed concerns the accentuation of the communicative relationship, the choice of symbolic languages and the primacy of the liturgical language. There is a lot of truth in these prospects but cognitive learning has an important role in education without which there cannot be self-direction and even conscious transformation, but only a temporary imitation with the risk of new forms of religious socialization. It is a fact that contemporary pedagogy has revalued the transformative approach typical of „reflexivity”.

Certainly modern catechesis had put a stop to teaching as memorising. To overcome the pedagogical formalism of "teaching the truth" it has developed a methodological figure that can be defined as "pedagogical education”; but in fact this was conveyed by a pedagogy of the cognitive age. As a reaction to this obvious pedagogical failure, however, a part of catechetical reflection preferred to consider evangelization defined as "communication of the faith." It is in this perspective that the current emphasis on the different forms of the relationship between catechesis and narration (and biography) is to be considered. ${ }^{73}$ But we should not confuse the narrative pedagogy that belongs to the preaching domain with biographical catechesis that precisely seeks to enable the response of faith.

Contemporary pedagogy is re-proposing the dimension of reflexivity. This practice is not the equivalent to the "truthful instance" which was erroneously and forcibly re-introduced in the ' 80 s and ' 90 s of the past century. In fact this means joining the level of "self-reflection” of external knowledge (traditions and Christian languages) to the inner world, making them interact in an adequate way. These dimensions are the emotional memory, unconscious knowledge, and knowledge of the different manifestations of the self. Reflexivity underlines in a special way the "understanding" of the emotions which a type of formation or proposal evokes and the understanding of the resistances that block their assimilation.

${ }^{72}$ L. Meddi, Educare la risposta della fede, p. 118-120.

${ }^{73}$ G. Cucci, La maturità dell'esperienza di fede, Civiltà Cattolica-Elledici, Roma-Torino 2010, p. 149-184. 
As we were reminded repeatedly by E. Morin „The present teaching provides knowledge without teaching what knowledge is ... one should therefore teach what is relevant... It is pertinent to know how to situate it in its context and in addition to the whole to which it is connected.' It is relevant to always connect knowledge to the context ... teaching must help the mind to use its natural aptitude to situate partial and global objects in their context, in their complexity, as a whole ... it must be analytical and synthetic at the same time, able to grasp mutual relations, the mutual influences, the inter-retro-actions. ... 'Finally, the knowledge of knowledge requires us to permanently practice reflexivity, that is, self-examination, which eventually leads to self-criticism, to think about our thoughts, which also implies to think of them in historical, cultural and social conditions of our existence." ${ }^{74}$

From this point of view the practice of Christian meditation ${ }^{75}$ has now expanded by connecting reflection on scripture and tradition to the understanding of the intrapsychic "resonance" that they cause. The various forms of deep meditation or transcendental meditation were also enriched in the Christian practice by this second moment of reflection that comes from eastern meditative practice: self-awareness in front of the Gospel proposal. This shift or enrichment of meditative practice leads more easily to the healing of resistance or difficulty (shadows of Jungian language) of the believer in the realization of his/her conversion. ${ }^{76}$ Even in this aspect help comes from psychological practice.

We must not be afraid to affirm that Christian practice needs a Yoga. Yoga is a practice that addresses the deeper problems of life. It is an age-old philosophy. The first traces of the word is found in the Hindu sacred texts dating from the fifth century BC. The hatha yoga (the most practiced in the West is "gymnastics" for the body) is part of raja yoga which has been codified by Patanjali, in the third or second century BC. According to this teacher, awareness is limited by many obstacles which if one needs to exceed, one has to do so through a challenge. ${ }^{77}$ There is a relationship between the laws of the higher life and life at the physical

${ }^{74}$ E. Morin, La via. Per l'avvenire dell'umanità, p. 142-144 passim [Riforma dell'educazione, p. 139-148].

${ }^{75}$ K. Tilmann, H.T. von Peinen, Guida alla meditazione cristiana, 2 vols., Queriniana, Brescia 1980.

${ }^{76}$ R. Assagioli, Lo sviluppo transpersonale, second part.

77 Patanjali, Yogasutra, a cura di F. Squarcini, Einaudi, Torino 2015. Patanjali outlines the itinerary in 8 stages; it is made up of interior and exterior practices. 
level. The etymology of the word means Union. It is the same etymology that we find in the Gospel word yoke. The yoga practitioner (a disciple who follows the sadhana, ${ }^{78}$ the way) has as its ultimate goal the union with God. It is therefore a path to free the individual soul from the narrow ego that lives in separation (from others, from the world or universe, and from God).

There are different types of yoga. The four main ones are those which apply awarness to feelings, to action, to the will, and to knowledge. The purpose is to know God as a real Person. For this it is necessary to recognize that everything in the world is provisional and temporary. When we identify with the culture of the world we remain in an illusion which is considered as ignorance. Knowledge of the truth is the contemplation of the Absolute.

The pillars of this construction appear to be the biographical and the narrative dimensions. These function provided that the dimensions cross at the level of reflexivity, awareness and consciousness.

The practice of spiritual knowledge has as its objective to broaden the perspective, the view, within which to understand one's own life. This practice sometimes requires the healing of the self-perception so helshe can see what hel she can not because of the socialization (cultural and affective) received. The practice of knowledge is fed both by the practice of teaching and the spirituality of nature. I cannot deny that in this perspective the formulation of a journey of profound conversion still needs the analysis of educational progressions which are proper to the objectives. ${ }^{79}$ From my point of view, consciousness is the real way to overcome intellectualism in catechesis. However it is still a long way away.

\section{The Basic Skills}

Many authors of spirituality and formation for the Christian life have taken this path of mediation to accompany the deep conversion of sympathizers, of those who re-discover the faith and of believers themselves. From their teachings and from my personal training I can pinpoint some skills that can be understood as basic skills for the process of conversion. They do not form the „content” of the

${ }^{78}$ A reflection which is between Christian praxis and yoga can be found in: A. de Mello, Sàdhana. Un cammino verso Dio, ELP, Roma 1980; il cammino è organizzato secondo tre passaggi: consapevolezza, immaginazione, devozione.

${ }^{79}$ I refer to the different taxonomies and classifications of the objectives of education. 
Christian life, and they do not replace the liturgical-sacramental dimension of faith. They are "competences" in the sense that they help in the preparation to welcome the Spirit.

\section{Silence}

In spiritual practices, more than in psychological ones the journey of conversion-purification begins by acquiring the skills of silence and of concentration. These are connected to each other. In the interior silence the conscience sinks from the exterior level of the senses to the introspection of the heart. In the operations of the mind it is still perceived in a dual way, whilst in the intuitive perception we understand the fundamental unity of reality. Silence has to do with the body and the mind and allows meditation as awareness and openness to Christian values, that is, Christian introspection. ${ }^{80}$

Like other Authors, A. Grün ${ }^{81}$ lists a long series of daily opportunities through which we can educate ourselves to silence in view of the concentration or the primary spiritual unity. For him, „silence consists of 'silencing all the thoughts that continue to surface ... [through] renouncing to judge everything ... Silence existed before me and regardless of me ... inside us there is a the space for silence" (8.10). Silence is an initial competence, but accompanies the whole transformative path, thus becoming a constant dimension. M. Ballester ${ }^{82}$ writes that in the essence of the soul there is no activity and for this reason we can describe silence at different levels; that which is psychosomatic, of the body; that of the soul as the invocation of the Supreme Name, overcoming the trivial self, that of the spirit that is gradual, but also hampered and conditioned by death. ${ }^{83}$

Concentration comes from silence and allows the person to make himself available to profound knowledge. Inside each of us there is a space in which we are allowed to be fully ourselves. It is the basis for the development of awareness

${ }^{80}$ S. Painadath, Il potere di trasformazione del silenzio contemplativo, «Concilium», p. 47-61. Here p. 48 .

${ }^{81}$ Ritrovarsi nel silenzio. Esperienze monastiche per la vita quotidiana, Queriniana, Brescia 2009. Cf. also A. Gentili, A. Schnoller, Dio nel silenzio. Manuale di meditazione, Ancora, Milano 2009.

${ }^{82}$ M. Ballester, L’ultimo silenzio della meditazione profonda, conferenza presso il centro "Appunti di viaggio" 1998, 26 aprile.

${ }^{83}$ An itinerary is described in: J. Marquez Fernadez, Vita e contemplazione. Itinerario pratico alla vita interiore, San Paolo, Cinisello Balsamo 1993. 
and meditation because they create the interior space. ${ }^{84}$ Silence and concentration are helped by relaxation practices and deep breathing. ${ }^{85}$

\section{Meditation}

Through silence we are allowed to develop meditative skills. Meditation is part of the Christian spiritual tradition ${ }^{86}$ especially after this surpassed the perspective centred on the practice of penance and asceticism understood as a punishment to the body. Meditation exceeds this passive perspective and develops the human potential of consciousness. Christian meditation groups want to achieve three objectives: the strengthening of self, knowledge and healing of the inconsistencies of the personality in front of the message, and the internalization of the mysteries of the Christian life.

First of all, meditation ${ }^{87}$ develops the ability of the self to guide the choice of transformation. „The end of meditation is the union of the individual with the source of life, with the Universal Mind, the Creator, whatever you want to call him. The mechanism that pushes us forward can be of two types: to seek control of our mind, the development of its powers, or look for the right use of the mind for spiritual purposes .... The exercises may be the same, but the motivation will make a difference in the results you will get. The difference in the results depends on the motivation. It is important therefore to often repeat the question about the true source that pushes us forward."

A decisive step in the journey of authentic conversion is the knowledge and the healing of the inconsistencies of the personality (the egoistic ego) when faced with the Christian message. ${ }^{88} \mathrm{M}$. Ballester, ${ }^{89}$ one of the founders of

${ }^{84}$ A. Grun, Lo Spazio interiore, Queriniana, Brescia 2008.

${ }^{85}$ R. A. Bigi Falcinelli, N. Pileri, Io respiro, tu respiri, non ci ispiriamo. Note di meditazione e di didattica per bambini e adolescenti, Edizioni Appunti di viaggio, Roma 1999.

${ }^{86}$ Congregazione per la Dottrina delle Fede, Lettera ai Vescovi della Chiesa Cattolica su alcuni aspetti della meditazione cristiana, 1989, recalls the specific Christian doctrine but also the importance of psycho-physical and bodily methods (ch. VI).

${ }^{87}$ F. Silvani, Meditazione per tutti. Tutte le forme e tutti gli aspetti della meditazione, il punto di partenza di ogni crescita interiore, Jackson Libri, Cesena 1998, 5-6. Cf. also J. Main, La via della meditazione, La Meridiana, 2008.

88 R. Assagioli, lo sviluppo transpersonale, second part.

89 M. Ballester, Meditazione profonda e autocoscienza, Emp, 2007. Cf. his Iniziazione alla preghiera profonda, EMP, Padova 1987. Cf. also A. Gentili, A. Schnoller, Dio nel silenzio. Manuale di meditazione. 
a particular school of a "deep meditation method" sums up the journey of meditation in this way, „In the last decades of the last century techniques and meditation practices proper to the treasury of Eastern religions have profoundly influenced the approach to the spiritual dimension proper to the Western world. From this the way of deep meditation and self-knowledge (MPA) whose purpose is to guide the practitioner towards the source of his being through a spiritual search process was born".

In his works he describes this list of meditative content: the desire, desires, analysis of emotions, of mental representations, the search for the centre, the choice of Christ as the centre.

Another Author ${ }^{90}$ equally engaged in paths of internal liberation gives greater emphasis to the liberation of the unfinished socialization: the inner and cultural assumptions of the revolution of this world; the distortions of the family; the tremendous mystery of universal alienation; and the correction of all the distorted images of God, of the human being and of the world.

About the properly Christian aims - the internalization of the mysteries of the Christian life - Ch. A. Bernard ${ }^{91}$ reminds us „It is a work of assimilation of what the eye has read, of what the ear has heard, of what memory considered; a "portion" and to ruminate of ideas in order to penetrate them completely ... The aim will be to lead the spirit to investigate in a complete way the various aspects of the mystery and to implement the will; the heart is the practical conduct to the teaching meditated upon ... For Ignatius ,the best known of these methods is that of the three powers: memory, intelligence and will subsequently applied to different aspects of the mystery being pondered upon. By itself such a succession of different acts is perfectly natural and respects the usual process of our thinking" (948-949).

Meditation as a practice has been described in many publications and resources. Besides the practice of the „ways” described above, we must mention those related to self-awareness: imagination, the search for emotional connections, the observation of resistance and contradictions, the evolutionary reconstruction of one's own childhood, the language of dreams, confrontation with the inner Spirit, lectio and the Gospel, spiritual workshops and resonances, the forms of autobiography and of the spiritual diary, confrontation as a group and many others.

${ }^{90}$ M. Guzzi, Yoga e preghiera cristiana. Percorsi di liberazione interiore, Paoline, Milano 2009.

91 Ch. A. Bernard, Meditazione, in Nuovo dizionario di Spiritualità, p. 947-954. 


\section{Spiritual Exercises and other Practices}

By the term „spiritual exercises” we mean every way of examining the consciousness, to meditate, contemplate, pray vocally and mentally, and other spiritual activities aimed at preparing and disposing the soul to get rid of all disordered affections and, once it has outgrown them, to seek and find God's will in organizing one's life for the salvation of the soul. ${ }^{92}$ This approach already belongs to the Greek and Roman culture. ${ }^{93}$

In this perspective it is also useful to re-take some of the traditional aspects of asceticism, not in the sense of the self that excludes both faith and grace ${ }^{94}$ but only in the pedagogical and the formative-enabling dimension. We intend the expression as used by A. Cencini, ${ }^{95}$ that is as exercises that help to deconstruct the self ego and to restore it in following the Gospel. He recalls that the human sciences confirm that asceticism and discipline are not ends in themselves but means to acquire a new and authentic freedom. Areas and contents: the relational dimension and the personal dimension.

I add to this definition the exercises which are proper to the Christian life. Through practice, even initial practice, the different contents of the faith experience of the self are put in a confrontational position with the self, recognizing the gifts received but also the interior resistances that the new commandment of love asks of us. In this way they can be healed better.

92 M. Rotsaert, Gli esercizi spirituali di sant'Ignazio - Storia, contenuto, metodo, finalità, San Paolo, Cinisello Balsamo 2015. Here he cites the Esercizi spirituali 1, Ia Annotazione. On a more anthropological note, but adjacent, cf. W. James, The Energies of Men, Moffat-Yard and Company, New York 1914.

93 P. Hadot, Esercizi spirituali e filosofia antica. Nuova edizione ampliata, Einaudi, Torino 2005, p. 30-31. After having refused phrases such as "thinking exercises, intellectual exercises, ethical exercises", the Author re-presents the expression "spiritual exercises" because "according to him, it allows us to understand how these exercises are not only limited to thought but they are linked to all the physical aspect of the individual, and above all reveal the true dimensions of these exercises; thanks to them, the individual is elevated to the life of the objective Spirit or in other words the prospective of the Eternal ("exceeding oneself by entering the realm of the eternal")".

${ }^{94}$ C. Montanari, A. Angelini, G. Simonelli, Ascesi e figura cristiana dell'agire. Atti della Giornata di studio (Milano, 20 gennaio 2005), Glossa, Milano 2005.

95 A. Cencini, Larte del discepolo. Ascesi e disciplina. Itinerario di bellezza, Paoline, Milano 2010. 
In the light of this pedagogical setting ${ }^{96}$ of educatingleducating oneself through exercises it will be helpful to review the catechetical praxis in relation to the acquisition of skills. This approach may seem far removed from the catechetical practice but it is not so at all. Catechesis ${ }^{97}$ has redesigned itself in terms of a true inculturation-acculturation of the faith. Some Authors ${ }^{98}$ identify the basic steps: biographical awareness, understanding the experience in cultural contexts, the critical and evangelizing comparison with the sources of faith, personal reflexivity, and the decision to change.

\section{Conclusion}

The observations mentioned in this research do not concern the whole task of catechesis in the time of the (New) Evangelization in the different ecclesial context, and especially in Europe. They are linked to conversion as a process of inner response to the gift of faith. In this perspective, conversion as an initial intuition and a progressive transformation is an action of the Spirit through the human spirit. The content of the conversion is metanoia-discipleship, so it is the Gospel and needs a specific ecclesial responsibility that we call evangelization. From this point of view conversion is not identified with the accompanying intra-psychic processes. These come into play in supporting the response of faith. We can say that the spirituality of conversion refers to the development of the Christian personality capable of deciding for the faith and the practice of Christian life. This great work appears to us the specific task of catechesis and catechetics.

Translated by Carl-Mario Sultana, University of Malta

${ }^{96}$ It seems very useful to keep in mind the indications which come from practicing coaching: P. Sabatino, Il Group Coaching. Sviluppare il potenziale dei piccoli gruppi in formazione, Franco Angeli, Milano 2014; Le développement personnel, Christus, 245 (2015), 1.

97 L. Meddi, Educare la risposta della fede, p. 158-160.

98 T. H. Groome, Christian religious education. Sharing our story and vision, HarperColins Publishers Ltd., New York 1980, ch. IX: Shared Christian Praxis, p. 184-206; A. Fossion, La catéchèse dans le champ de la communication. Ses enjeux pour l'inculturation de la foi, Cerf, Paris 1990, c. XIII; L. Meddi, Il processo di interiorizzazione della fede, in «Note di Pastorale Giovanile» 38 (1998) 8, p. 33-52. 